\title{
GARŚĆ UWAG O SEMANTYCZNYM ZAANGAŻOWANIU SOCJOLOGÓW
}

Uzasadniona wydaje się opinia, że stopień osobistego zaangażowania autora na różnych etapach badań naukowych znacząco wpływa na ich końcowy rezultat. Oddziaływanie to ujawnia się szczególnie ${ }^{1}$ w naukach społecznych, w których im większa liczba osobistych, filozoficznych, religijnych, politycznych czy moralnych zależności, w które jest uwikłany naukowiec, tym mniej obiektywne mogą stać się analizy dotyczące określonego przedmiotu badawczego. Choć istnieją różne poglądy na temat bezstronności naukowca, do miana klasycznej urasta opinia Maxa Webera, który twierdził, że jakkolwiek możliwa jest neutralność semantyczna, to jednak warunki społeczne i osobowościowe „zakorzenione" w danej społeczności eliminują możliwość zachowania neutralności w praktyce. Jak postaram się dowieść, sytuacja

${ }^{1}$ Wpływ własnych przekonań badaczy społecznych jest wyraźnie widoczny, ponieważ sami naukowcy najczęściej posiadają przed rozpoczęciem badań jakieś przekonanie na temat jego obiektu. Wydawałoby się, że wpływ taki nie występuje wśród osób zajmujących się naukami przyrodniczymi, a tym bardziej formalnymi, jak matematyka i logika, jednak i to nie jest oczywiste. Por. np. I. Lakatos, Dowody i refutacje. Logika odkrycia matematycznego, przeł. M. Kozłowski, K. Lipszyc, Tikkun, Warszawa 2005. 
wygląda jeszcze gorzej, bowiem wspominana przez Webera neutralność semantyczna również nie jest możliwa. Nie jest ona możliwa, ponieważ nie istnieje osoba nieuwikłana w jakąś filozofię języka, przyjmowaną najczęściej implicite. Istotność tego uwikłania, i jego konsekwencje, w postaci kształtowania możliwych do podejmowania działań i interpretacji, spróbuję pokazać konfrontując neopozytywistyczną filozofię języka oraz konsekwencje jej przyjęcia, w przypadku prowadzenia badań z zakresu socjologii religii. Spróbuję także przedstawić (przynajmniej prowizorycznie) pewne środki zaradcze, neutralizujące wpływ języka na bezstronność badawczą.

Granice tego, co można wypowiedzieć oraz tego, co można zrozumieć, wyznaczają granicę możliwych dociekań. Jest to dość oczywiste: jak poucza klasyk, o czym nie można mówić, o tym należy milczeć ${ }^{2}$. Sytuacja byłaby prosta, gdyby panowała zgoda co do tego, o czym można mówić oraz co można zrozumieć. Aprobowana, przynajmniej w nauce, relacja między mówieniem i rozumieniem, jest następująca: należy mówić o tym, co da się zrozumieć. Jeśli bowiem nadawca tworzy zdanie, które odbiorca odczytuje zgodnie z jego intencjami, mamy do czynienia z procesem komunikacji. Używając języka filozofii analitycznej należy powiedzieć, że chodzi tutaj o zdania, które mają sens (meaning ${ }^{3}$ ).

Każdy świadomy człowiek - niezależnie od różnych czynników - musi podejmować się oceny sensowności zdań. Musi na przykład wiedzieć, że jeżeli słyszy „aaaaarrrrhhh” podczas gdy ktoś

${ }^{2}$ L. Wittgenstein, Tractatus logico-philosophicus, przeł. B. Wolniewicz, PWN, Warszawa 2000, s. 83

3 „Meaning” w większości słowników angielsko-polskich tłumaczy się jako „znaczenie”. W tłumaczeniach anglojęzycznej filozofii analitycznej termin ten oznacza zarówno polskie „znaczenie”, jak i „sens” właśnie. „Sensowność poznawcza" to na przykład ,cognitive meaningfulness". 
ziewa, to odgłos ten nie tworzy zdania. Musi także wiedzieć, że jeśli dziecko gaworzy i pokazuje coś palcem, to komunikat ten może być impresywny i oznaczać „daj mi to”. Tym samym musi wiedzieć, że nawet dźwięki nietworzące słów mogą coś oznaczać, wyrażać jakąś intencję. Słowa „musi” używam tutaj w dwóch znaczeniach. Po pierwsze, w znaczeniu społecznym, związanym z regułami płynnego dialog $u^{4}$. Po drugie logicznym - działając świadomie pod wpływem gaworzenia dziecka wskazującego palcem przedmiot, przypisanie temu gestowi sensu jest ukrytym założeniem i warunkiem koherencji systemu przekonań.

Porozumienie odbywa się jednak przede wszystkim za pomocą słów. W większości chodzi o słowa mające jasno sprecyzowany desygnat: słoń, tramwaj, sonata, księżyc. Co do sensowności tych słów panuje powszechna zgoda. Można jednak bez specjalnego przygotowania i wysiłku stworzyć słowo, które nic nie znaczy takie, które nie posiada desygnatu, na przykład „niertnik”. Na pytanie, czy niertnik istnieje, nie można odpowiedzieć „tak” lub „nie”, ponieważ nie wiadomo, co kryje się za tym słowem, a więc jaki jest jego desygnat. Dopiero ustalenie znaczenia słowa „niertnik" sprawi, że będzie można określić wartość logiczną zdania, w którym słowo to zostało użyte.

Istnieją jednakże słowa, które przez różne filozofie języka są wyłączane ze zbioru słów sensownych. Szczególne kontrowersje wywołują słowa odwołujące się do introspekcji, bez odwołania do której niemożliwe byłoby powstanie wielu gałęzi refleksji teoretycznej, na przykład fenomenologii czy socjologii rozumiejącej, a także zdania religijne związane z kategorią transcendencji,

${ }^{4}$ Kto kwestionuje reguły płynnego dialogu naraża się na ostracyzm, o czym przekonuje znany eksperyment przerywania Garfinkla (zob. H. Garfinkel, Studia z etnometodologii, przeł. A. Szulżycka, PWN, Warszawa 2007, s. 59-60). 
które są obecne w socjologii religii. Szczególnie restrykcyjne kryteria sensowności słów pochodzą od przedstawicieli filozofii neopozytywistycznej lub bliskim jej myślicielom. Wspomnieć należy o kryterium weryfikacji, kryterium falsyfikacji oraz kryterium odniesienia.

Zasadę weryfikacji tak opisuje Alfred Jules Ayer:

Twierdzimy, że zdanie posiada dla danej osoby sens wtedy i tylko wtedy, gdy wie ona jak zweryfikować sąd, który zdanie to wyraża - to jest, jakie obserwacje prowadziłyby ją, pod pewnymi warunkami, do uznania [tego sądu] za prawdziwy lub fałszywy. Natomiast jeśli dana hipoteza zakłada swoją prawdziwość lub fałszywość w związku ze swoją potwierdzalnością w przyszłości to, jeśli nie jest tautologią, jest tylko pseudo-hipotezą. Wyrażenie to może mieć dla kogoś znaczenie emocjonalne, ale nie ma faktycznego sensu'.

Jeśli więc nasz sąd wyrażamy poprzez zdanie „W drugim pokoju stoi krzesło", to zakładając, że potrafimy zidentyfikować pojęcia „krzesło” i „drugi pokój”, warunkiem weryfikacji tego sądu będzie udanie się do drugiego pokoju i zaobserwowanie, czy rzeczywistość jest zgodna ze stanem opisywanym przez to zdanie. Jeśli naocznie przekonamy się, że krzesło znajduje się w pokoju,

${ }^{5}$,We say that a sentence is factually significant to any given person, if, and only if, he knows how to verify the proposition which it purports to express that is, if he knows what observations would lead him, under certain conditions, to accept the proposition as being true, or reject it as being false. If, on the other hand, the putative proposition is of such a character that the assumption of its truth, or falsehood, is consistent with any assumption whatsoever concerning the nature of his future experience, then, as far as he is concerned, it is, if not a tautology, a mere pseudo-proposition. The sentence expressing it may be emotionally significant to him; but it is not literally significant": A.J. Ayer, Language, truth and logic, New York 1952, s. 35, tłum. własne - Ł.R. 
uznamy to zdanie za prawdziwe. Jeśli nie, jest ono fałszywe. Jednak w obu przypadkach mamy do czynienia ze zdaniem sensownym, ponieważ byliśmy w stanie powziąć kroki, aby je zweryfikować.

Rozważmy jednak inne zdanie: „Planeta Mars jest z sera”. Zdanie to wydaje się sensowne, ponieważ wiemy, czym jest „Mars”, wiemy także, czym jest „ser”. Jednak z faktu, że nie potrafimy zweryfikować tego zdania wynikałoby, że jest ono pozbawione sensu, co wyraźnie kłóci się ze zdrowym rozsądkiem. Zmusiło to Ayera do rozdzielenia weryfikacji na praktyczną i teoretyczną ${ }^{6}$. Przykład Marsa dotyczy weryfikacji praktycznej. Natomiast weryfikacja teoretyczna to taka, która stanowi opis warunków, jakie musiałyby zajść, aby zdanie uznać za prawdziwe: „Wiem jednak jakich obserwacji musiałbym dokonać, gdybym znalazł się w odpowiednim miejscu by je poczynić. A zatem mimo, że hipotezy tej praktycznie nie da się jej zweryfikować, teoretycznie jest weryfikowalna, a zatem ma sens" ${ }^{7}$. Ponadto Ayer postuluje rozróżnienie weryfikacji silnej (strong) i słabej (weak) ${ }^{8}$. Silna opiera się na wykazaniu prawdziwości sądu w sposób konkluzywny, przez doświadczenie. W podanym wcześniej przykładzie z krzesłem byłoby to po prostu wskazanie: „Oto krzesło w drugim pokoju”. Jednak weryfikacja konkluzywna jest niemożliwa w stosunku do zdań wyrażających sądy ogólne, takie jak „Arszenik to trucizna”, „Wszyscy ludzie są śmiertelni”. W tym przypadku weryfikacja musi z konieczności opierać się na prawdopodobieństwie, a kolejne świadectwa potwierdzające dany sąd zwiększają prawdopodobieństwo jego prawdziwości.

\footnotetext{
${ }^{6}$ Tamże, s. 36.

${ }^{7}$ Tamże.

${ }^{8}$ Tamże, s. 37.
} 
Zasadę weryfikacji krytykuje Karl Popper. Krytyka dotyczy w pierwszej kolejności weryfikacji jako metody sprawdzania teorii naukowych. Zauważa, że nawet z nieskończonej ilości obserwacji potwierdzających daną teorię w żaden sposób nie wynika logicznie jej pewność. Natomiast teorię naukową można w sposób konkluzywny obalić, wskazując przypadek, który nie jest $\mathrm{z}$ nią zgodny. Wprowadza więc w miejsce weryfikacjonizmu własne narzędzie - falsyfikacjonizm. Powodem, dla którego Popper decyduje się na użycie tego narzędzia, jest także kryterium demarkacji ${ }^{10}$. Jest to kryterium, które winno pozwolić na stwierdzenie, które teorie posiadają pewne cechy metafizyczne, które zaś mają charakter empiryczny.

Wydaje mi się, że wybór zasady weryfikacji prowadzi do dylematu: albo sprowadzimy nauki przyrodnicze do metafizyki z powodu nieuzasadnialności ich ogólnych tez, co jest absurdalną konsekwencją „,silnej” weryfikacji, albo też będziemy uzasadniali owe teorie probabilistycznie, co z kolei jest niezgodne z logiką. Należy jednak podkreślić, że Popper nie uznawał falsyfikacjonizmu za kryterium sensowności, w przeciwieństwie do neopozytywistów, którzy weryfikacjonizm za takie kryterium uważali. Nie zmienia to faktu, że zarzuty, jakie w kierunku weryfikacjonizmu zgłosił Popper, były na tyle poważne, że w mojej ocenie należałoby uznać, iż to właśnie falsyfikacjonizm jest granicą rozdzielającą zdania sensowne i zdania nie posiadające sensu.

Trzecim kryterium jest kryterium odniesienia, nieuwikłane tak bardzo w filozofię nauki, które przedstawia Bohdan Chwedeńczuk w następującej formule, zainspirowanej filozofią Davida Hume'a:

${ }^{9}$ K.R. Popper, Logika odkrycia naukowego, przeł. U. Niklas, PWN, Warszawa 1977, s. 29.

${ }^{10}$ Tamże, s. 34. 
Słowo ma charakter poznawczy wtedy i tylko wtedy, gdy odnosi się, pośrednio lub bezpośrednio, do doświadczenia. Rozumiemy je, gdy potrafimy go użyć, w zdaniu rozstrzygalnym przez doświadczenie ${ }^{11}$.

W niniejszym artykule nie interesuje mnie, czy wymóg Hume'a jest słuszny czy nie. Jako że punktem centralnym jest perspektywa empirystyczna, wystarczy mi na tym etapie rozważań stwierdzenie, że wszystkie argumenty przeciw temu wymogowi Chwedeńczuk odpiera ${ }^{12}$. Kryterium przedstawione przez Chwedeńczuka znacząco różni się od poprzednich propozycji. Podczas gdy Ayer utożs a miał sens oraz weryfikowalność (znaczenie sądu to sposób jego weryfikacji), dla Chwedeńczuka relacja do doświadczenia jest tylko warunkiem do uzyskania przez słowo pewnego atrybutu - a mianowicie sensowności (dalej posługuje się on tym słowem w zastępstwie „charakteru poznawczego”).

Wymóg ów opiera się więc nie na możliwości potwierdzenia lub zaprzeczenia sądom, zawierającym zdanie, o którym chcemy rozstrzygnąć czy podpada czy też nie podpada pod ten wymóg. Chodzi natomiast o jakąkolwiek możliwą, obiektywną i odpowiedzialną ocenę tego sądu. Chwedeńczuk przytacza przykład pojęcia „sprawiedliwość społeczna”, który jest wszak stosunkowo niejasne, a już na pewno nie posiada desygnatu w rozumieniu rzeczy materialnej. Jednak, zdaniem Chwedeńczuka, możemy się nim posługiwać, ponieważ odpowiada ono pewnym układom i zachowaniom społecznym, rozdziałowi dóbr, przywilejom władz etc.

${ }^{11}$ B. Chwedeńczuk, Przekonania religijne, Aletheia, Warszawa 2000, s. 58. Zob. także o zastosowaniu wymogu Hume'a do analizy zagadnienia definicji religii: Ł. Remisiewicz, Jak filozofia empirystyczna zmienia myślenie socjologa na temat religii, „Studia Philosophica Wratislaviensia” 2011, nr 3, s. 109-122.

${ }^{12}$ B. Chwedeńczuk, Przekonania..., s. 61-107. 
„Rozumiemy te wyrażenia, gdy znamy - mówiąc krótko - ich związki znaczeniowe z wyrażeniami, które rozumiemy, bo je wiążemy z naszymi doznaniami zmysłowymi" ${ }^{13}$. Poza tym, jak mi się wydaje, nawet jeśli nie jesteśmy w stanie konkluzywnie wykazać, że w danym przypadku „sprawiedliwość społeczna” istnieje, to spieramy się mimo wszystko o rzeczy „znane” z doświadczenia. Posiadamy więc elementarną odpowiedzialność za słowo. Możemy się spierać, czy dany układ dóbr i przywilejów wyczerpuje, czy też nie wyczerpuje znamion „sprawiedliwości społecznej”, ale jest to spór o coś konkretnego, o pewne konkretne fenomeny, które kategoryzujemy, choć co prawda arbitralnie. Możemy ponadto umówić się, że określone warunki będą rozstrzygały kwestię podlegania uwarunkowaniom „sprawiedliwości społecznej”.

Podsumowując ten fragment rozważań należy stwierdzić, że wskazaliśmy trzy kryteria, które niezależnie od siebie - według różnych empirystów - decydują o sensowności wyrażeń. Kryteria weryfikowalności i falsyfikowalności uznają za sensowne takie zdania, które da się konkluzywnie, kolejno potwierdzić lub im zaprzeczyć. Kryterium odniesienia natomiast ujmuje zdania sensowne jako te, które odnoszą się pośrednio lub bezpośrednio do doświadczenia.

Mówiąc „Na stole leży książka”, wydaję komunikat sensowny, ponieważ w określonych okolicznościach jestem w stanie rozstrzygnąć, czy zdanie to jest prawdziwe czy fałszywe. Potrafię więc rozstrzygnąć jego wartość logiczną. Tak samo będzie w wypadku zdania: „Na stole leży dźwięk”. Rozumiem wszystkie słowa w tym zdaniu, więc bez wątpliwości muszę uznać, że czynność leżenia nie jest atrybutem, jaki można przypisać dźwiękowi. Zdanie jest

${ }^{13}$ Tamże, s. 53. 
więc fałszywe. Inaczej przedstawia się sytuacja w przypadku zdania: „Na stole leży dusza”. Nie wiemy, jakie atrybuty może, a jakich nie może mieć „dusza”; nie wiemy, czym ona jest, a przynajmniej czym jest w kategoriach empirycznych. Władysław Piwowarski mówi, że dobra definicja to taka, że po przedmiocie danym w doświadczeniu da się rozstrzygnąć, czy podpada on czy też nie podpada pod dany termin ${ }^{14}$.

Zdanie sensowne to takie, któremu możemy przypisać wartość logiczną - prawdy lub fałszu. Każdy uznaje pewne zdania za sensowne, inne zaś za bezsensowne. Co więcej, każdy mus i uznawać pewną pulę zdań za sensowne. Pierwszą kategorią zdań uznawanych za sensowne są własne, informatywne wypowiedzi. Jeżeli wypowiadamy jakiś sąd, niemal zawsze wypowiadamy go z intencją komunikacji. Przyjmujemy, że zostanie on odczytany zgodnie z naszymi założeniami. Naukowiec również musi uznawać pewne minimum zdań za sensowne. Otóż musi nade wszystko uznawać za sensowne zdania własnej metodologii, zawierające wskazówki dotyczące procedur badawczych. Musi także za sensowne uznawać własne wypowiedzi. Decyzja o tym, jakiej klasy zdania uważamy za sensowne, jest decyzją podejmowaną na polu filozoficznym. Nawet jeśli decyzja taka jest przyjmowana implicite, świadomy metodologicznie badacz powinien umieć uzasadnić, jakiego rodzaju kryterium posługuje się, by odróżnić sens od bezsensu.

Przyjąć należy, że decyzje w zakresie uznawania jakiejś filozofii języka są po pierwsze arbitralne, a po drugie szczere. Poprzez stwierdzenie, że są arbitralne chcę powiedzieć, iż są one wyborem podjętym w oparciu o jedną z dostępnych, alternatywnych filozo-

${ }^{14}$ W. Piwowarski, Socjologia religii, Redakcja Wydawnictw Katolickiego Uniwersytetu Lubelskiego, Lublin 1996, s. 25. 
fii języka. Innymi słowy: różne, często nieintuicyjne filozofie są równouprawnione z tymi uchodzącymi za zdroworozsądkowe. Decyzje dotyczące filozofii języka są szczere, to znaczy nie zostały przyjęte jedynie hipotetycznie, ale są realnymi zespołami poglądów. Kto przyjmuje więc filozofię języka wyłączającego ze zbioru zdań sensownych daną klasę zdań, pozbawia się możliwości odnoszenia do niej w zakresie całej swojej działalności językowej. Przykładowo, jeśli ktoś uważa za bezsensowne wszystkie zdania, w których podmiotem jest słowo „Bóg”, uznać musi za bezsensowne wszystkie wywiady, analizy, ankiety, w których słowo to pada.

W tym minimalnym rozumieniu każdy socjolog, czy szerzej naukowiec, jest zaangażowany w problem o charakterze filozoficznym i każdy rozwiązuje go w pewien sposób, często w sposób nieświadomy. Nieświadomość bycia uwikłanym w spór oczywiście w żaden sposób tego uwikłania nie umniejsza. Uznawanie pewnych zdań za sensowne albo bezsensowne jest wartościowaniem nie tyle aksjologicznym, co epistemologicznym. Zdania bezsensowne to zdania bez wartości, nawet w logicznym tego słowa znaczeniu. Zdania sensowne są wartościowe dlatego, że można nadać im wartość logiczną. To właśnie sądzenie o wartościach jest swoistym zaangażowaniem - na polu ideologicznym lub filozoficznym. Ideologiczność nie przeczy oczywiście filozoficzności, zaś filozofia może zamienić się $\mathrm{w}$ ideologię. Zaangażowanie filozoficzne, objawiające się $\mathrm{w}$ arbitralnym doborze epistemologicznych założeń, jak każde wartościowanie jest niezbędną praktyką każdego badania: „[...] sądy wartościujące i odchylenia ideologiczne są w socjologii nieuniknione, a nawet dopuszczalne na heurystycznym etapie doboru problemu lub tematu badawczego, ale powinny być wykluczone przy ostatecznych wynikach i ich uzasadnieniu. A wszystkie wartości, jak radził Gunnar Myrdal, 
powinny być wyrażone wprost i poddane dyskusji”"15. Współcześni socjologowie, jak wynika z moich obserwacji, nie zdają sobie zazwyczaj sprawy ze swojego semantycznego zaangażowania. Rzecz jasna, trudno wyobrazić sobie sytuację, w której każde słowo w każdej pracy byłoby szczegółowo uzgadniane w oparciu o kryterium sensowności. Nie o takie rozwiązanie chodzi. Myślę jednak, że przedstawienie jasnego kryterium sensowności słów w codziennej praktyce badawczej i sprawozdawczej nie byłoby trudne, a jednocześnie czyniłoby zadość radzie Myrdala.

Kryterium sensowności jest rzeczą pewnego wyboru, pewnej decyzji filozoficznej. Stanowisk jest wiele, socjolog ma więc wiele wariantów, które ze słów uznać za sensowne i na jakich warunkach. Może jednak przecież dojść do sytuacji, że jego pracę czyta osoba, która posługuje się zgoła odmiennymi kryteriami. Czy jest ona zdana na to, by uznać cały wysiłek za intelektualny bełkot?

Janusz Mariański jest znanym socjologiem moralności i religijności. $\mathrm{W}$ jednym $\mathrm{z}$ badań na temat postaw młodych ludzi wobec tych dwóch systemów kulturowych autor ten pyta, czy respondent: ,- Wierzy w istnienie siły wyższej, która rządzi światem? - Wierzy w istnienie Boga osobowego? - Wierzy, że istnieje Bóg w trzech osobach? - Wierzy, że Bóg jest stwórcą świata i/lub człowieka?" ${ }^{16}$. Truizmem jest powiedzieć, że Mariański uznaje pytanie o istnienie „Boga w trzech osobach” za zdanie sensowne. Gdyby było inaczej, pytanie o tę kwestię nie mogłoby paść. Nie bierze jednak pod uwagę faktu, że respondent mógłby uważać to pytanie za pozbawione poznawczego znaczenia, ponieważ kafeteria musi

${ }^{15}$ P. Sztompka, Dziesięć tez o statusie socjologii w świecie nierówności, „Globalny Dialog" 2007, nr 2.2, s. 17.

${ }^{16}$ J. Mariański, Kondycja religijna i moralna młodych Polaków, Nomos, Kraków 1991, s. 96-98. 
być w tym przypadku ograniczona do odpowiedzi implicite przyjmujących sensowność tego pytania, zróżnicowanych jedynie pod względem przyznania twierdzeniu o istnieniu „Boga w trzech osobach" odpowiedniej wartości logicznej.

Załóżmy jednak, że tak spreparowaną ankietę bierze do ręki, przeprowadza i analizuje neopozytywista uznający któreś z wyżej nakreślonych kryteriów sensowności. Czy badanie takie jest dla niego całkowicie bezwartościowe? Otóż bynajmniej. Przyjmijmy, że chcemy zbadać, jaką religię r e aln i e wyznaje respondent. Nie od dziś wiadomo, że pomiędzy religią „deklarowaną" a religią wyznawaną jest często faktycznie spory dystans. Możemy, dla każdej z interesujących nas religii, sporządzić matrycę gotowych odpowiedzi, składających się z deklaracji doktrynalnych. Każda religia miałaby więc swój własny „wzór odpowiedzi”, wyznaczający zakres jej wierzeń. Następnie, porównując odpowiedzi respondenta dotyczące jego deklaracji doktrynalnych, moglibyśmy porównać i zawyrokować, czy religia deklarowana jest dokładnie ta sama, co religia realnie wyznawana.. Warto przy tej okazji dodać, że tego typu działanie nie wymaga od socjologa rozumienia doktryny danej religii. Uznanie przez respondenta zdania religii P za prawdę można zdefiniować jako dopisanie do niego słów ,jest prawdziwe". Nie oznacza to, że jest ono faktycznie (empirystycznie) prawdziwe, fałszywe lub w ogóle bezsensowne. Zostało jednak za takie uznane, został przydzielony mu taki status, którego jawnym znakiem jest zaznaczenie go jako „prawdziwego" lub poczynienie deklaracji równoznacznych.

Wydaje się, że mutatis mutandis podobny sposób analizy można zastosować wszędzie tam, gdzie koniecznością nie jest analiza sensu wypowiedzi, a sam fakt danej wypowiedzi. Fakt danej wypowiedzi bardzo często, przez samo połączenie z pewnymi instytucjami, daje pole do analizy. 
Istnieją więc deklaracje, które według filozofii empirystycznej nie posiadają poznawczego sensu, ale mogą być mimo wszystko przydatne do analizy w pewnych konkretnych sytuacjach. Istnieją jednak także komunikaty i wnioski badawcze, których częścią są słowa lub zdania kontrowersyjne z punktu widzenia analizowanej tu filozofii. Oddajmy głos Franciszkowi Adamskiemu:

Wiara w życie pozagrobowe, znana u wszystkich ludów i w każdej kulturze, wolne od wszelkich ograniczeń w realizacji samego siebie pragnienie osiągnięcia pełni szczęścia o znacza nic innego, jak pragnienie samego Boga i dążenie do Niego: życie i szczęście wieczne utożsamia się z Bogiem - On tylko jest wieczny, wszechmocny i tylko w Nim znajdują uosobienie upragnione przez człowieka najwyżse wartości, które stanowią dobro, prawda, piękno, miłość i doskonałość. Tęskniący za tymi wartościami człowiek w naturalny sposób otwiera się na ich źródło. Wobec T r a n s c e nde ncj i człowiek zajmuje postawę religijną, to znaczy uznaje istnienie pierwiastka boskiego (sacrum), oddaje Mu cześć i podporządkowuje swe życie wyznaczonym normom ${ }^{17}$.

Cytowane dzieło nosi tytuł Socjologia religii, jest więc z założenia dziełem naukowym, nauka zaś posługuje się komunikatami i formułuje hipotezy - wyrażenia możliwe do interpretacji i dyskusji. Dyskutować można zaś tylko z czymś, co się rozumie. Tymczasem z punktu widzenia filozofii empirystycznej, pragnienie „Boga” i „dążenie do Niego”, a także postawy „wobec Transcendencji" musiałyby być zdefiniowane w kategoriach empirycznych. Gdy zaś jako takie zostałyby zdefiniowane, nie mogłyby dotyczyć

${ }^{17}$ F. Adamski, Socjologia religii, Petrus, Kraków 2010, dostępny w internecie: http://www.opoka.org.pl/biblioteka/I/IK/petrus_2010_soc_reg_00.html, dostęp: 2 V 2014, podkreśl. Ł.R. 
niczego transcendentnego. Toteż wnioski, które wyraża Adamski, nie mogą być podstawą dyskusji z empirystą.

Można oczywiście argumentować, że to empirysta traci na tym, że zamyka się na pewne sensy ukryte w wypowiedziach odnoszących się do sfery pozaempirycznej. Wypada jednak w tym miejscu zauważyć, że empirysta wcale nie zamyka się, lecz z przyjętych założeń wnioskuje o niemożliwości zrozumienia pewnych słów z powodów „naturalnych”, a nie przygodnych (którymi mogłyby być jego chęci lub ich brak). Przy odpowiedniej dozie precyzji dałoby się, rzecz jasna, stworzyć pewnego rodzaju model, w którym zachowania ludzkie nazywalibyśmy wskaźnikiem kontaktu z Transcendencją. Jednak w języku empirysty zachowania te nie byłyby wskaźnikiem, lecz de sygnate m wyrażenia „kontakt z Transcendencją". Wyrażenie to stosujemy bowiem wobec obserwowalnego zachowania X, nie mając nic innego, co moglibyśmy określić tym mianem lub wnioskować o jakichś sytuacjach, których zachowanie X miałoby być indykatorem. Z pewnością nie o to chodzi cytowanemu Franciszkowi Adamskiemu.

Osoby występujące $\mathrm{z}$ twierdzeniem o bezsensowności zdań religii są oczywiście w mniejszości, stąd trudno się dziwić, że również w socjologii stanowią niewielką grupę. Jak starałem się jednak pokazać, różnorodność poglądów filozoficznych na naturę sensu może doprowadzić do nieporozumień. Dlatego w mojej opinii uczciwe badanie powinno rozpocząć się od pytania, ile jesteśmy w stanie powiedzieć o obiekcie badań, to właśnie bowiem wyznacza jasno granicę realnego przedmiotu, jak i sposobu analizy. Przyjęcie i jasne określenie wyznawanej filozofii języka jest zasadniczym krokiem do rozjaśnienia przedmiotu swoich badań, jak i poszerzenia refleksji na temat własnej metodologii, również tej nieuświadomionej. Tym bardziej, że przedstawione zagadnienia to mikroskopijny ułamek problemów, na jakie nara- 
żone są współczesne prądy socjologiczne w rodzaju fenomenologii czy wszelkich odmian postmodernizmu. Bardzo potrzebna jest dziś debata o tym, co fakt y c zn i e chcemy poznać i naukowo zakomunikować. Efektowność socjologicznej poezji nie zawsze idzie bowiem w parze z efektywnością komunikacji.

\title{
FEW REMARKS ON THE SEMANTIC ENGAGEMENT OF SOCIOLOGISTS
}

\author{
SUMMARY
}

There is a common opinion that a researcher cannot be entirely objective. Although they can keep a semantic neutrality, their identity and social environment make it impossible to maintain this neutrality in the practice. The author tries to prove that this neutrality is impossible as well because every scientist chooses their own philosophy of language. The author shows examples of certain statements of sociology of religion confronted with three positivist requirements and ways in which the choice can influence the interpretation. We can translate the statements to become compatible with the requirements of the language but every translation is subject to risk of losing the depth, the root of thinker's intention. Since there are many opposite views on philosophy of language a need arises to develop a sociological thought concerning this aspect of their work.

KEYWORDS

meaning, objectiveness, philosophy of language, sense, sociology of religion 